\title{
Expanding the genetic basis of copy number variation in familial breast cancer
}

\author{
Amy L Masson ${ }^{1,4}$, Bente A Talseth-Palmer ${ }^{1,4}$, Tiffany-Jane Evans ${ }^{1,4}$, Desma M Grice ${ }^{1,2}$, Garry N Hannan² \\ and Rodney J Scott ${ }^{1,3,4^{*}}$
}

\begin{abstract}
Introduction: Familial breast cancer ( $\mathrm{fBC}$ ) is generally associated with an early age of diagnosis and a higher frequency of disease among family members. Over the past two decades a number of genes have been identified that are unequivocally associated with breast cancer (BC) risk but there remain a significant proportion of families that cannot be accounted for by these genes. Copy number variants (CNVs) are a form of genetic variation yet to be fully explored for their contribution to fBC. CNVs exert their effects by either being associated with whole or partial gene deletions or duplications and by interrupting epigenetic patterning thereby contributing to disease development. CNV analysis can also be used to identify new genes and loci which may be associated with disease risk.

Methods: The Affymetrix Cytogenetic Whole Genome 2.7 M (Cyto2.7 M) arrays were used to detect regions of genomic re-arrangement in a cohort of $129 \mathrm{fBC} B R C A 1 / B R C A 2$ mutation negative patients with a young age of diagnosis ( $<50$ years) compared to 40 unaffected healthy controls ( $>55$ years of age).

Results: CNV analysis revealed the presence of 275 unique rearrangements that were not present in the control population suggestive of their involvement in BC risk. Several CNVs were found that have been previously reported as BC susceptibility genes. This included CNVs in RPA3, NBN (NBS1), MRE11A and CYP19A1 in five unrelated $\mathrm{ABC}$ patients suggesting that these genes are involved in $B C$ initiation and/or progression. Of special interest was the identification of WWOX and FHIT rearrangements in three unrelated $\mathrm{ABC}$ patients.

Conclusions: This study has identified a number of CNVs that potentially contribute to BC initiation and/or progression. The identification of CNVs that are associated with known tumour suppressor genes is of special interest that warrants further larger studies to understand their precise role in $\mathrm{fBC}$.
\end{abstract}

Keywords: Breast cancer, DNA repair, CNV

\section{Introduction}

Global cancer statistics identify $\mathrm{BC}$ as the most frequently diagnosed cancer $(23 \%)$ and leading cause of cancer related death (14\%) in females [1]. Nearly $27 \%$ of these BCs occur in a familial setting typically associated with an earlier age of disease diagnosis and a higher frequency among family members and is termed $\mathrm{fBC}[2,3]$. It is estimated that $5-10 \%$ of these families harbor germline mutations or complex genomic changes that render inactive one of four high penetrance genes (BRCA1, BRCA2, TP53 or PTEN)

\footnotetext{
* Correspondence: Rodney.Scott@newcastle.edu.au

'Information Based Medicine Program, Hunter Medical Research Institute, University of Newcastle, Newcastle, NSW 2305, Australia

${ }^{3}$ Division of Molecular Medicine, Hunter Area Pathology Service, John Hunter Hospital, Newcastle, NSW 2305, Australia

Full list of author information is available at the end of the article
}

or moderate penetrance genes (CHEK2, ATM, BRIP1 and $P A L B 2)[2,4,5]$. Associations have also been identified for other genes in $\mathrm{fBC}$ including ATM, CASP8, CTLA4, NBN, CYP19A1, TERT, and XRCC3 [6]. The most recent BC meta-analysis has identified 41 loci and suggests that over 1000 loci may be involved in disease susceptibility [7]. The identification of $B R C A 1$ and $B R C A 2$ as susceptibility genes for $B C$ and the more recent addition of PALB2, BRIP1 and RAD51C [5] have focused attention on genes associated with double strand break repair (DSBR). There are at least 39 genes implicated in DSBR, all of which could potentially be associated with BC risk. This is analogous to DNA mismatch repair (MMR), where there are at least 21 genes associated with this process, of which four are now routinely assessed and more recently a fifth gene 
(POLD1) has been added to the list $[8,9]$. Despite the plethora of information regarding genetic loci associated with $\mathrm{BC}$ risk, for many $\mathrm{ABC}$ cases no genetic predisposition has been identified. Outside the context of gene mutations other mechanisms may be associated with disease development including gene silencing as a result of epigenetic re-programming of $\mathrm{BC}$ susceptibility genes (analogous to loss of EPCAM and the re-arrangement of the epigenetic profile on chromosome 2, rendering $M S H 2$ inactive $[10,11])$, or mutations in genes not yet associated with a predisposition to disease.

One type of genetic alteration that could account for susceptibility is genetic re-arrangements detected as CNVs. CNVs represent a class of structural variation involving regions of duplication or deletion of genomic material that can encompass large stretches of genomic sequence ranging from megabases (Mbs) to a few kilobases $(\mathrm{Kb})$ in size. As a consequence, CNVs can contribute to disease when they incorporate functional gene sequence (coding and promoter regions of genes) or exert more cryptic effects, that could affect epigenetic regulation (methylation, microRNA targets) and non-coding intronic gene sequences [12-23]. Two reports have recently examined CNVs in association with $B R C A 1 / B R C A 2$ mutation negative $\mathrm{fBC}$ patients. The first of these has reported a greater abundance of rare CNVs in $\mathrm{ABC}$ patients and suggest that rare $\mathrm{CNVs}$ are likely to contain genetic factors associated with $\mathrm{BC}$ predisposition, while the second report associated several $\mathrm{CNV}$ markers with $\mathrm{fBC}$ risk and suggests their use in disease risk assessment $[24,25]$.

The detection of CNVs has historically relied upon the use of DNA arrays, typically comprised of oligonucleotide markers distributed across the whole genome. The resolution of DNA arrays has increased to allow for the detection of genomic rearrangements as small as a few $\mathrm{Kb}$ in size. In this study we used the Affymetrix Cyto2.7 M array which provided the highest genomic coverage of any commercially available microarray at the time of assay to assess $\mathrm{CNV}$ variation in an $\mathrm{ABC}$ cohort. The Cyto2.7 $\mathrm{M}$ array contains a combination of 400,000 single nucleotide polymorphisms (SNPs) and $>2.1$ million copy number probes (average spacing 1395 base pairs (bp)) which together can be used to accurately detect genomic rearrangements.

We conducted a patient-control analysis examining $129 \mathrm{fBC}$ patients and 40 control subjects derived from the same population to identify CNVs which could be associated with the genetic basis of their disease. To date this study represents one of the largest $\mathrm{CNV}$ studies of $B R C A 1 / B R C A 2$ mutation negative $\mathrm{fBC}$ patients.

\section{Materials and methods Samples}

The study was approved by the University of Newcastle's Human Research Ethics Committee and the Hunter
New England Human Research Ethics Committee. Genomic DNAs were obtained from $\mathrm{ABC}$ patients who had given informed consent for their DNA to be used for studies into their disease and control DNA samples from the Hunter Community Study (HCS) [26]. DNA was extracted from whole blood by the salt precipitation method [27].

A cohort of 129 patients clinically diagnosed with earlyonset $\mathrm{ABC}$ were used in this study. All patients had been diagnosed with $\mathrm{BC}$ and were the first individual (proband) of their family to seek genetic testing for mutations in BRCA1/BRCA2. Mutation screening was performed using Sanger Sequencing and Multiplex ligation-dependant probe amplification (MLPA) analysis. No mutations were identified in any of the patients (BRCA1/BRCA2 mutation negative). The average patient age was calculated to be $<40.7$ years. Genomic DNA from 40 controls [26] was also utilized in this study. These were healthy (cancer free) individuals aged $>55$ years at the time of sample collection.

\section{Genomic array preparation and data processing}

The genomic DNA from $129 \mathrm{fBC}$ patients and 40 controls were processed on the Affymetrix Cyto2.7 M array consistent with manufacturer's protocols. CEL files were analysed in Affymetrix, the Chromosome Analysis Suite (ChAS) (Version CytoB-N1.2.0.232; r4280) using NetAffx Build 30.2 (Hg18) annotation. Quality control (QC) parameters were optimized and validated using a training set of 20 randomly selected samples. All samples were subject to a series of quality cut-off measures: snpQC $>1.1$ (SNP probe $\mathrm{QC}$ based off distances between the distribution of alleles $(\mathrm{AA}, \mathrm{AB}$ and $\mathrm{BB})$ where larger differences are associated with an increased ability to differentiate genotype; default), mapdQC $<0.27$ (Median Absolute Pair-wise Difference; $\mathrm{CN}$ probe $\mathrm{QC}$ based off a reference model; default) and wavinessSd $<0.1$ (measure of standard deviation in data waviness; the GC content across the genome correlates with average probe intensities i.e. high GC probes are brighter than low GC probes on average, creating waves in the data). CNV regions were assessed according to call confidence, probe count, size and by visual inspection for distinction from normal $\mathrm{CN}$ state. Data was also visually inspected to identify regions with low density of markers (Additional file 1: Table S1) which were excluded across all samples. Most thresholds were more stringent than default settings alone in an aim to minimize false-positive $\mathrm{CNV}$ s being included in the analysis. $\mathrm{CNV}$ regions were filtered across all samples using the following parameters: $>90 \%$ confidence, autosomes only and a minimum number of 24 probes. Using these parameters the limit of detection was $9.65 \mathrm{~Kb}$ across all samples used in the current study. This does not exclude the possibility of CNVs smaller than this from contributing to disease in a proportion of $\mathrm{ABC}$ patients. 


\section{CNV and statistical analysis}

CNVs in $\mathrm{fBC}$ patients and controls were subject to a series of comprehensive analyses which included: (1) interrogation for CNVs residing in or $\pm 100 \mathrm{~Kb}$ of 61 genes (associated with DSBR, MMR and BC susceptibility) and 41 SNPs recently reported to be associated with $\mathrm{BC}$ risk [6,7,28,29] (see Additional file 1: Tables S2 and S3); (2) comparison of $\mathrm{CNVs}$ between $\mathrm{fBC}$ patients and controls according to $\mathrm{CN}$ occurrence and distribution across the genome; (3) identification of rare CNVs using the Database of Genomic Variants (DGV); and (4) the identification of genes associated with malignancy (non-specific) using the Network of Cancer Genes (Version 3.0) and the Cancer Gene Census (CGC; 15 March 2012) databases [30,31]. Associations (e.g. numbers and sizes of CNVs) were statistically compared using a two tailed un-paired t-test Graphpad Prism (Version 6) [32].

\section{Validation of CNV results}

$\mathrm{CNV}$ results were validated using pre-designed TaqMan Copy Number (CN) Assays (Applied Biosystems). Up to two $\mathrm{CN}$ assays were selected within the $\mathrm{CNV}$ region indicated by the Cyto2.7 M array and $\mathrm{CN}$ assays, proximal but external to the region were also selected as controls (assay information summarized in Additional file 1: Table S4). A total of 11 samples were run in triplicate comprised of the sample(s) of interest, a calibrator (control) sample with known $\mathrm{CN}$ for the region of interest and a no-template-control (NTC). Real-time PCR was conducted according to manufacturer's protocols using $10 \mathrm{ng}$ of DNA sample in a final reaction volume of $20 \mu \mathrm{L}$. The assay was run on the real-time PCR machine (Applied Biosystems 7500; SDS software Version v1.4) according manufacturer's protocols. The results were exported to CopyCaller v2.0 software (Applied Biosystems) for analysis.

Three CNVs were validated using this secondary independent assay (Additional file 1: Table S5). The CNVs included a $\mathrm{CN}$ gain and a $\mathrm{CN}$ loss in the $W W O X$ gene as well as a $\mathrm{CN}$ loss in the FHIT gene. Given the high concordance between the CNV calling within the experimental parameters set for this study and the independent copy number assays we considered that it was not necessary to confirm all CNVs using a second independent assay.

\section{Results}

Array resolution and CNV detection

Analysis of Cyto2.7 M array data revealed a total of 414 CNVs in 169 individuals assessed in this study (Table 1). CNVs detected ranged in size from 9.65 Kb to 1335.06 $\mathrm{Kb}$. There was no difference in the average number of CNVs identified in the patients versus the controls $(p=$ 0.75). The average genomic burden of CNVs also did not differ between patients $(226.93 \mathrm{~Kb})$ and controls $(295.52$ $\mathrm{Kb}), \mathrm{p}=0.30$; or the average CNV size between patients (76.22 Kb) and controls (106.57 Kb), s, $p=0.07$.

\section{Occurrence and distribution of CNVs in $\mathrm{fBC}$ patients}

Overall $310 \mathrm{CNVs}$ were identified in $\mathrm{fBC}$ patients of which 35 also occurred in controls (Additional file 1: Table S6). Since these regions were represented in the control population they were removed from further analysis. Of the $275 \mathrm{CNVs}$ unique to the patients (Additional file 1: Table S7), 94 have was previously described in the DGV and 39 spanned genomic regions that were common to multiple patients (Table 2). Of these 11 CNVs (located on chromosomes 2, 3, 4, 6, 11, 14, 15, 17 and 18) were common to two patients; three were common to three patients (located on chromosomes 4, 5 and 19 ); and two were common to four patients (located on chromosomes 3 and 18). Among these, three genomic regions (located chromosomes 6, 11 and 19) were considered novel (not reported in the DGV) and likely to represent regions of potential association with $\mathrm{BC}$ risk.

Of the CNVs unique to patients 160 (58.18\%) encompassed genes. A CNV located in SUPT3H was also excluded from analysis as it was identified to be affected by a re-arrangement in a control sample and considered unlikely to be associated with disease risk. Therefore a total of 159 genes were associated with a CNV were identified as being unique to the $\mathrm{ABC}$ patients and represent genes potentially associated with disease. A total of 24 genes associated with $44 \mathrm{CNVs}$ (gains, losses or both) were identified in multiple individuals (as shown in Table 3): 19 genes, including $L A M B 3, N B N, I L 8$ and WWOX, were affected by a CNV in two individuals; PIK3R5 and POU2F3 were affected by a CNV in three individuals; ARHGEF12 and TMEM136 were affected by a CNV in four individuals; and NAMPT was affected by a CNV in five individuals.

Table 1 Summary of CNV results from the BC patients and control participants

\begin{tabular}{|c|c|c|c|c|c|c|c|}
\hline & & \multicolumn{3}{|c|}{ CNV Count } & \multicolumn{3}{|c|}{ CNV Size (Kb) } \\
\hline & & $\begin{array}{l}\text { Total CNVs } \\
\text { per group }\end{array}$ & $\begin{array}{l}\text { Median CNVs } \\
\text { per sample }\end{array}$ & $\begin{array}{l}\text { Mean CNVs } \\
\text { per sample }\end{array}$ & $\begin{array}{l}\text { Total CNV affected } \\
\text { genome per group }\end{array}$ & $\begin{array}{l}\text { Mean total CNV affected } \\
\text { genome per sample }\end{array}$ & $\begin{array}{l}\text { Mean size } \\
\text { of a CNV }\end{array}$ \\
\hline Patients & 129 & 310 & 2 & 2.40 & 29273.63 & 226.93 & 76.22 \\
\hline Controls & 40 & 104 & 2 & 2.60 & 11820.75 & 295.52 & 106.57 \\
\hline$p$ & - & - & - & 0.75 & - & 0.30 & 0.07 \\
\hline
\end{tabular}


Table 2 Genomic regions associated with unique CNVs identified in multiple patients

\begin{tabular}{|c|c|c|c|c|c|}
\hline Type & Chr & Start (bp)* & End $(b p)^{*}$ & Size (Kb) & Probes \\
\hline \multicolumn{6}{|c|}{2 CNV gains } \\
\hline Gain & 2 & $13,119,088$ & $13,199,687$ & 80.6 & 48 \\
\hline Gain & 2 & $13,135,013$ & $13,199,687$ & 64.7 & 43 \\
\hline Gain & 2 & $82,055,473$ & $82,163,764$ & 108.3 & 85 \\
\hline Gain & 2 & $82,056,404$ & $82,168,370$ & 112.0 & 89 \\
\hline Gain & 3 & 958,296 & $1,012,953$ & 54.7 & 33 \\
\hline Gain & 3 & 975,908 & $1,032,700$ & 56.8 & 29 \\
\hline Gain & 6 & $27,738,385$ & $27,764,062$ & 25.7 & 26 \\
\hline Gain & 6 & $27,742,403$ & $27,770,374$ & 28.0 & 24 \\
\hline Gain & 15 & $79,783,294$ & $79,876,946$ & 93.7 & 77 \\
\hline Gain & 15 & $79,795,446$ & $79,876,343$ & 80.9 & 70 \\
\hline Gain & 17 & $21,503,478$ & $21,648,413$ & 144.9 & 25 \\
\hline Gain & 17 & $21,503,478$ & $21,650,626$ & 147.2 & 26 \\
\hline \multicolumn{6}{|c|}{$3 \mathrm{CNV}$ gains } \\
\hline Gain & 4 & $25,672,202$ & $25,703,024$ & 30.8 & 31 \\
\hline Gain & 4 & $25,678,621$ & $25,710,178$ & 31.6 & 32 \\
\hline Gain & 4 & $25,680,434$ & $25,710,412$ & 30.0 & 31 \\
\hline Gain & 5 & $59,749,693$ & $59,807,906$ & 58.2 & 51 \\
\hline Gain & 5 & $59,749,693$ & $59,807,906$ & 58.2 & 51 \\
\hline Gain & 5 & $59,749,693$ & $59,810,944$ & 61.3 & 52 \\
\hline Gain & 19 & $36,911,234$ & $36,939,557$ & 28.3 & 36 \\
\hline Gain & 19 & $36,918,927$ & $36,940,929$ & 22.0 & 32 \\
\hline Gain & 19 & $36,918,927$ & $36,944,555$ & 25.6 & 36 \\
\hline \multicolumn{6}{|c|}{2 CNV losses } \\
\hline Loss & 11 & $95,844,428$ & $95,917,476$ & 73.1 & 54 \\
\hline Loss & 11 & $95,844,428$ & $95,917,476$ & 73.1 & 54 \\
\hline Loss & 14 & $44,229,915$ & $44,294,996$ & 65.1 & 53 \\
\hline Loss & 14 & $44,229,915$ & $44,294,996$ & 65.1 & 53 \\
\hline Loss & 17 & $19,439,549$ & $19,476,055$ & 36.5 & 28 \\
\hline Loss & 17 & $19,439,549$ & $19,476,055$ & 36.5 & 28 \\
\hline Loss & 18 & $1,714,779$ & $1,828,901$ & 114.1 & 109 \\
\hline Loss & 18 & $1,714,779$ & $1,828,901$ & 114.1 & 109 \\
\hline \multicolumn{6}{|c|}{4 CNV losses } \\
\hline Loss & 3 & $166,523,809$ & $166,565,186$ & 41.4 & 39 \\
\hline Loss & 3 & $166,523,809$ & $166,565,186$ & 41.4 & 39 \\
\hline Loss & 3 & $166,523,809$ & $166,566,558$ & 42.8 & 40 \\
\hline Loss & 3 & $166,525,250$ & $166,565,186$ & 39.9 & 38 \\
\hline Loss & 18 & $1,894,368$ & $1,974,284$ & 79.9 & 63 \\
\hline Loss & 18 & $1,894,368$ & $1,974,284$ & 79.9 & 63 \\
\hline Loss & 18 & $1,894,368$ & $1,974,284$ & 79.9 & 63 \\
\hline Loss & 18 & $1,894,368$ & $1,974,284$ & 79.9 & 63 \\
\hline \multicolumn{6}{|c|}{2 CNV gain and loss } \\
\hline Gain & 4 & $160,917,340$ & $161,068,954$ & 151.6 & 119 \\
\hline Loss & 4 & $160,983,513$ & $161,011,918$ & 28.4 & 29 \\
\hline
\end{tabular}

Probes $=$ number of markers within a CNV segment.

*set at first and last marker associated with the respective CNV.
Table 3 Genes associated with unique CNVs identified across multiple patients

\begin{tabular}{|c|c|c|c|}
\hline & Number of Patients & Gene & Loci \\
\hline \multirow[t]{11}{*}{ Gains } & 2 & $B 2 M$ & $15 q 21.1$ \\
\hline & 2 & DSCAM & $21 \mathrm{q} 22.2$ \\
\hline & 2 & GOS2 & $1 \mathrm{q} 32.2$ \\
\hline & 2 & GNG2 & $14 q 22.1$ \\
\hline & 2 & GPR98 & $5 q 14.3$ \\
\hline & 2 & IL8 & $4 q 13.3$ \\
\hline & 2 & LAMB3 & $1 \mathrm{q} 32.2$ \\
\hline & 2 & LIMS1 & $2 q 13$ \\
\hline & 2 & $N B N$ & $8 q 21.3$ \\
\hline & 2 & TAGAP & $6 q 25.3$ \\
\hline & 2 & TRIM69 & $15 q 21.1$ \\
\hline \multirow[t]{3}{*}{ Both } & 2 & CNTN4 & $3 p 26.3$ \\
\hline & 2 & IMMP2L & $7 q 31.1$ \\
\hline & 2 & WWOX & $16 q 23.1$ \\
\hline \multirow[t]{10}{*}{ Losses } & 2 & ACYP2 & $2 \mathrm{p} 16.2$ \\
\hline & 2 & $\mathrm{PCDH} 9$ & $13 q 21.32$ \\
\hline & 2 & SPINT4 & $20 q 13.12$ \\
\hline & 2 & TSPYL6 & $2 \mathrm{p} 16.2$ \\
\hline & 2 & VAV3 & $1 \mathrm{p} 13.3$ \\
\hline & 3 & PIK3R5 & 17p13.1 \\
\hline & 3 & POU2F3 & $11 q 23.3$ \\
\hline & 4 & ARHGEF12 & $11 q 23.3$ \\
\hline & 4 & TMEM136 & $11 q 23.3$ \\
\hline & 5 & NAMPT & $7 q 22.2$ \\
\hline
\end{tabular}

Rare CNVs in $\mathrm{fBC}$ patients

There were 95 rare CNVs identified in 42 of the $\mathrm{fBC}$ patients. Of these 70 were associated with 78 genes and were found in 27 patients. Out of the 78 genes SUPT3H was excluded from further analysis as it was identified in a healthy control subject. Ten genes that were disrupted due to the presence of a CNV had previously been associated with cancer [30,31] including ARHGAP26, ARHGEF12, CARD11, CPD, FAM135B, TSHR, MLLT11, PTK2B, RHOH and FHIT (Table 4). The remaining CNVs affecting 67 genes were unique and have not previously been associated with malignancy (listed in Additional file 1: Table S8). These genes potentially represent new candidates that require further investigation.

Genomic changes involving BC susceptibility genes or the recently identified $B C$ susceptibility loci

There are at least 61 genes including those involved in DNA DSBR and MMR that could potentially contribute to $\mathrm{fBC}[6,7,28,29]$. CNV data for the $129 \mathrm{fBC}$ patients and 40 controls was screened for genomic re-arrangements within or $\pm 100 \mathrm{~Kb}$ either side of these 61 genes. Five 
Table 4 Results for the ten CNVs associated with seven patients which affect genes previously associated with cancer

\begin{tabular}{lcccccc}
\hline Genes & Dx & Type & Chr & Start (bp) & End (bp) & Size (Kb) \\
\hline FHIT & 22 & Loss & 3 & $60,494,885$ & $60,632,282$ & 137.4 \\
CARD11 & 37 & Gain & 7 & $2,946,394$ & $2,996,375$ & 50 \\
FAM135B & 38 & Gain & 8 & $139,259,837$ & $139,306,535$ & 46.7 \\
ARHGEF12 & 51 & Gain & 11 & $119,697,081$ & $119,723,342$ & 26.3 \\
TSHR & $\sim 49$ & Gain & 14 & $80,659,512$ & $80,669,166$ & 9.7 \\
MLLT11 & 46 & Gain & 1 & $149,289,549$ & 149307059 & 17.5 \\
CPD & & Gain & 17 & $25,700,671$ & $25,756,973$ & 56.3 \\
RHOH & 28 & Gain & 4 & $39,864,888$ & $39,888,181$ & 23.3 \\
ARHGAP26 & & Gain & 5 & $142,147,309$ & $142,174,652$ & 27.3 \\
PTK2B & & Gain & 8 & $27,237,115$ & $27,333,842$ & 96.7 \\
\hline
\end{tabular}

Gene, age of patient diagnosis (Dx), CNV type (gain or loss), location (chromosome, start and end) and CNV size are indicated.

patients were identified to harbour $\mathrm{CN}$ gains located within or in the vicinity of four genes (Table 5): one within $R P A 3$ gene; two within the NBN gene; one $55.7 \mathrm{~Kb}$ upstream of the MRE11A gene and one other $89.2 \mathrm{~Kb}$ upstream of the CYP19A1 gene. All gains are predicted to result in disruption of the respective genes' coding sequence (via the insertion of additional genomic material which is expected to result in loss of function). With respect to the $N B N$ gene a CNV loss was also identified in a control residing in a region located $52.6 \mathrm{~Kb}$ downstream of the gene but did not appear to be associated with disruption of the coding sequence.

No CNVs were identified that were located in the same 41 genomic regions that have recently been reported as BC susceptibility loci [7].

The identification of a CNV that involved WWOX in two unrelated patients (see Table 6, Figures 1 and 2) was of interest as this gene is located in a fragile site (FRA16D) associated with cancer development and has been shown to interact with TP53 and ACK1 [33] and has recently been reported to be involved in breast carcinogenesis $[34,35]$. Together, this suggests that loss of function of WWOX could potentially be involved in $\mathrm{BC}$ susceptibility. One patient harboured a $\mathrm{CNV}$ gain that was predicted to disrupt the coding sequence of the gene via the insertion of additional genomic material whereas the other patient had a CNV loss that is expected to result in loss of function. Both of these changes were confirmed using an independent $\mathrm{CN}$ assay (see Additional file 1: Table S5). A number of recent reports have also correlated $\mathrm{BC}$ development with changes in the FHIT gene which similarly to WWOX is located in a fragile site $(F R A 3 B)$ and has again been linked to tumour development [36-43]. CNV analysis revealed a CN loss that encompassed FHIT (Table 6 and Figure 3) which was confirmed using an independent assay (Additional file 1: Table S5).

\section{Discussion}

The association between CNVs and $\mathrm{fBC}$ is yet to be fully defined. In this study we provide evidence that CNVs are a potential explanation for small but significant number of $\mathrm{ABC}$ patients who do not harbour germline mutations in known susceptibility genes.

Genomic resolution provided by microarray technology has increased significantly allowing for the discovery of ever smaller CNVs. The resolution of the array used in this study was limited to the identification of CNVs greater than $9.65 \mathrm{~Kb}$ in size, and hence we cannot rule out the potential involvement of smaller CNVs in the aetiology of $\mathrm{fBC}$. There have been a number of technical issues associated with the identification of CNVs that have compounded the difficulties in assessing the role of genomic rearrangements in disease. Different array platforms, software algorithms, batch effects and population stratification influence the accuracy of calls made to and comparisons of CNV data [44-46]. To help in reducing the influence of these effects a set of 40 older population controls was used as the basis to differentiate between $\mathrm{CNVs}$ associated with breast cancer and uninformative controls. All samples (both cases and controls) were processed on one platform and analysed using the same analysis software and experimental parameters. Comparison between the number and size of CNVs between patients and controls did not reveal any significant differences between cohorts. It is important to note the limited number of controls utilized in the current study

Table 5 Search results for regions containing CN gains and CN losses within $\pm 100 \mathrm{~Kb}$ the 61 genes associated with BC risk

\begin{tabular}{ccccccc}
\hline & Genes & Type & Chr & Start (bp) & End (bp) & Size (Kb) \\
\hline Patients & RPA3 & Gain & 7 & $7,670,435$ & $7,697,631$ & 27.2 \\
& NBN & Gain & 8 & $91,048,149$ & $91,070,004$ & 21.9 \\
& NBN & Gain & 8 & $91,050,795$ & $91,088,236$ & 37.4 \\
& $55.7 \mathrm{~Kb}$ upstream MRE17A & Gain & 11 & $93,922,391$ & $93,960,356$ & 38.0 \\
& $89.2 \mathrm{~Kb}$ upstream CYP19A1 & Gain & 15 & $49,507,272$ & $49,579,058$ & 71.8 \\
Control & $52.6 \mathrm{~Kb}$ downstream NBN & Loss & 8 & $90,913,791$ & $90,962,106$ & 48.3
\end{tabular}


Table 6 CNVs associated with fragile site FRA16D and FRA3B

\begin{tabular}{lllllll}
\hline Chr & Start (bp) & End (bp) & Size (Kb) & Gene & Probes & DGV \\
\hline $\mathbf{1 6}$ & $76,684,338$ & $76,929,109$ & 244.8 & WWOX & 222 & Reported \\
$\mathbf{1 6}$ & $76,947,909$ & $77,009,160$ & 61.3 & WWOX & 69 & Reported \\
$\mathbf{3}$ & $60,494,885$ & $60,632,282$ & 137.4 & FHIT & 158 & \\
\hline
\end{tabular}

CNV location (chromosome, start bp and end $\mathrm{bp}$ ) and size (Kb); as well as the confidence score associated with CNV call, the gene affected by the variant, the number of probes used to call the CNV and if the variant has previously been reported in the DGV.

represents a potential bias, however it is reassuring to note that despite this potential limitation, our observations are consistent with two previous reports on $\mathrm{fBC}$ (68 patients and 100 controls) and BRCA1-associated ovarian cancer (84 patients and 47 controls) [24,47].

We also identified 67 genes associated with novel $\mathrm{CNVs}$ that have yet to be linked with $\mathrm{BC}$ risk. It is interesting to note that many of these have been implicated in biological processes involving metabolism and biological regulation [48]. This provides the basis for further investigation into expanding the number of genes involved in $\mathrm{BC}$ development.

Our study has identified CNVs in close proximity to a number of genes previously associated with $\mathrm{BC}$ risk in a $\mathrm{fBC}$ cohort: ARHGEF12 has been proposed to be a candidate tumour suppressor gene in $\mathrm{BC}$ whereby its under expression (typically as a result of genomic loss) has been observed in $\mathrm{BC}$ cell lines and where re-induction of the gene resulted in reduced cell proliferation and colony formation [49]; Laminin 5 (LN5) genes (including $L A M B 3$ ) have been shown to exhibit reduced expression as a result of epigenetic inactivation in $65 \%$ of $\mathrm{BC}$ cell lines [50]; $N B N$ has been recently reported to be associated with $\mathrm{BC}$ risk [6]; and NAMPT has been shown to modify the effects of PARP inhibitors used in the treatment of triple-negative $B C$ s suggesting the potential for a combination of $N A M P T$ and PARP inhibitors in the treatment of this disease [51].

Of all the genes affected by a CNV identified in more than one patient, the most frequently reported for $\mathrm{BC}$ development has been aberrations in WWOX. This tumour suppressor gene has been shown to be critical for normal breast development [34] with mutations in exons 4 to 9 frequently observed in $\mathrm{BC}$ tumours [35]. High expression of WWOX has been shown to be beneficial in association with tamoxifen treatment [52]. We further evaluated two unrelated $\mathrm{fBC}$ patients, one harbouring a $\mathrm{CNV}$ gain and the other a CNV loss. In both cases, the genomic rearrangements are predicted to reduce WWOX expression and thereby contribute to disease risk. Our results suggest that inherited deficiencies in $W W O X$ are associated with disease but we could not demonstrate that these alterations were transmitted across generations due to ethical
A

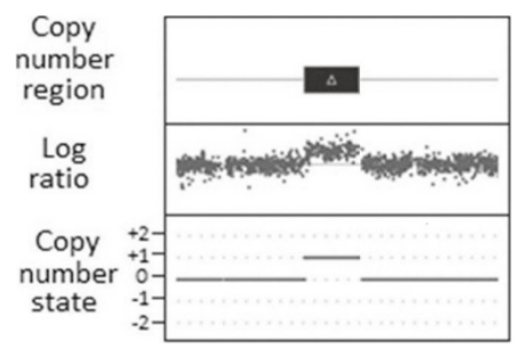

C

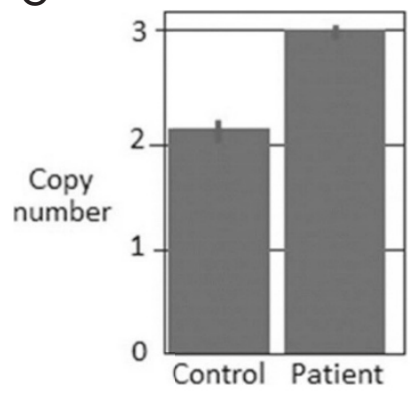

B

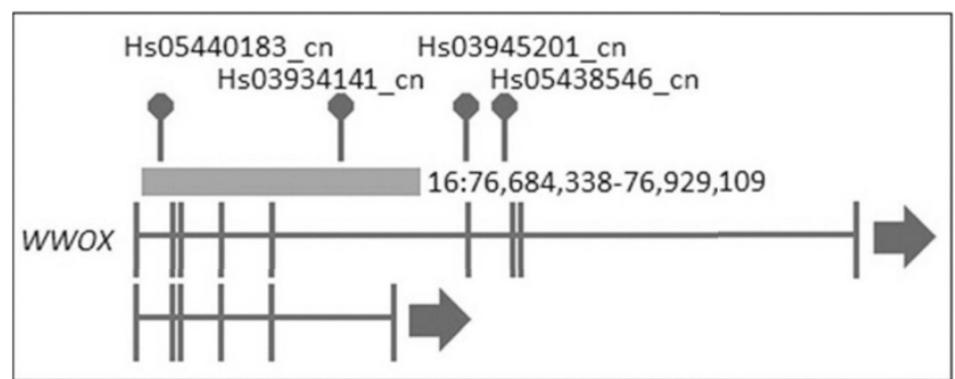

Figure 1 CNV results for WWOX duplication in fBC patient. (A) CNV profile from Cyto2.7 M array data defining the region of duplication including the genomic state (where $0=$ the normal two copies and $+1=$ one extra copy; (B) Location of the duplication within the gene and with respect to the CN assays used in validating the variant; and (C) TaqMan CN Validation assay showing the duplication represented by Hs03934141_cn: note the normal two copies of this region identified in the control, confirmation of the aberrant three copies in the fBC patient and the $\mathrm{CN}$ range bars associated with the three technical replicates used to validate the CNVs. 
A

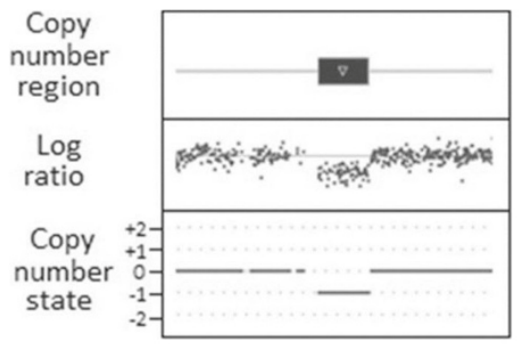

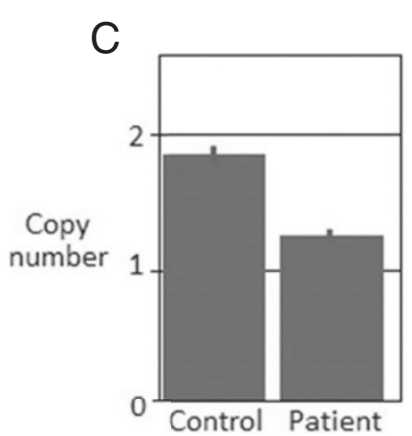

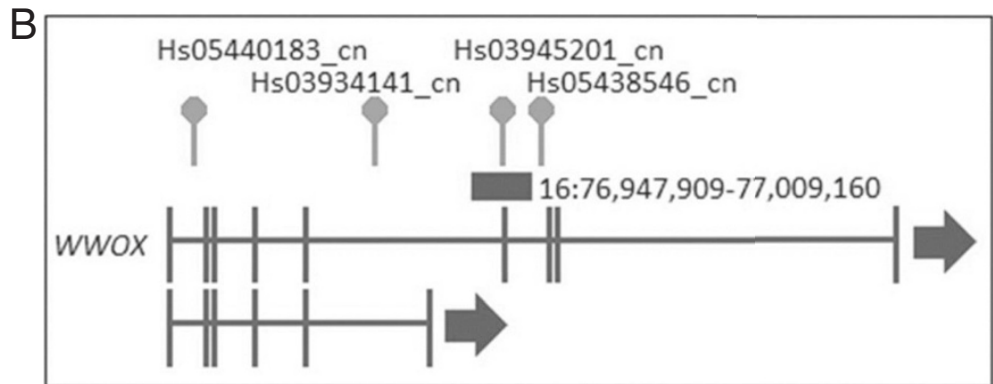

Figure 2 CNV results for WWOX deletion in $\mathrm{fBC}$ patient. (A) CNV profile from Cyto2.7 M array data defining the region of deletion including the genomic state (where $0=$ the normal two copies and $-1=$ one less copy; (B) Location of the deletion within the gene and with respect to the CN assays used in validating the variant; and (C) TaqMan CN Validation assay showing the deletion represented by Hs03945201_cn: note the normal two copies of this region identified in the control, confirmation of the aberrant one copy in the $\mathrm{fBC}$ patient and the $\mathrm{CN}$ range bars associated with the three technical replicates used to validate the CNVs.

A

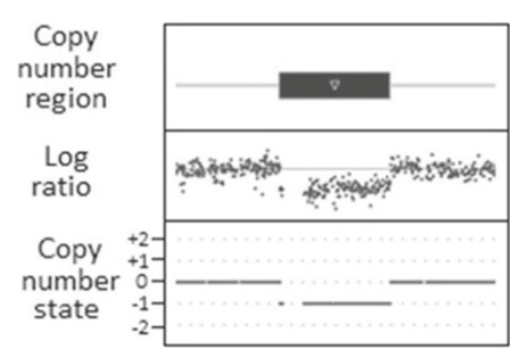

C

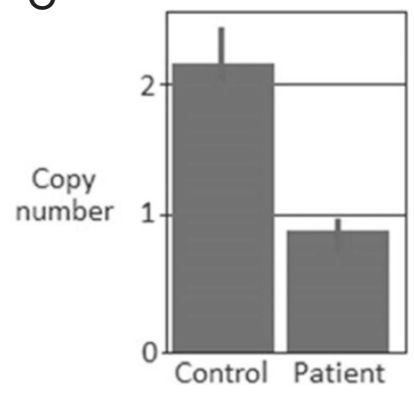

B

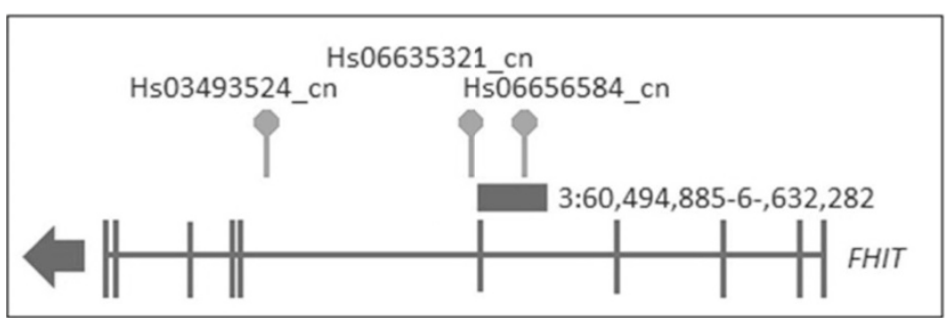

Figure 3 CNV results for FHIT deletion in $\mathbf{f B C}$ patient. (A) CNV profile from Cyto2.7 M array data defining the region of deletion including the genomic state (where $0=$ the normal two copies and $-1=$ one less copy; (B) Location of the deletion within the gene and with respect to the $C \mathrm{~N}$ assays used in validating the variant; and (C) TaqMan CN Validation assay showing the deletion represented by Hs06656584_cn: note the normal two copies of this region identified in the control, confirmation of the aberrant one copy in the $\mathrm{ABC}$ patient and the CN range bars associated with the three technical replicates used to validate the CNVs. 
considerations. Notwithstanding, the frequency at which we have observed variants occurring in this gene $(>1.55 \%)$ suggests that they may account for a significant proportion of $B R C A 1 / B R C A 2$ mutation negative $\mathrm{fBC}$ patients. Functional studies are required to determine the precise effect of these variants in the alteration of $W W O X$ expression and $\mathrm{BC}$ development.

The identification of CNVs in close proximity to $\mathrm{BC}$ susceptibility genes and loci that either contributes to disease development directly or via more cryptic means expands our understanding of their contribution to disease risk in $\mathrm{fBC}$. Our study identified $\mathrm{CNVs}$ residing in three genes RPA3, NBN, MRE11A and CYP19A1 which supports their involvement in $B C[6,28,29,53-56]$. Given the predicted disruption of $R P A 3, N B N, M R E 11 A$ and $C Y P 19 A 1$ it is likely that these variants are associated with disease.

Within our $\mathrm{fBC}$ cases we identified several genes within or in close proximity to rare CNVs which have previously been associated with $\mathrm{BC}$ : the putative oncogene MLLT11 (aka $A F 1 Q$ ) has been reported to be over expressed in a BC cell line affecting invasive and metastatic potential $[57,58]$; while $P T K 2 B$ has been shown to be the most frequently lost kinase in sporadic $\mathrm{BC}$ tumours and is suggested to contribute to the disease phenotype [59]. Of the rare CNVs associated with malignancy, the gene most frequently associated with BC development is the tumour suppressor FHIT. FHIT has been reported multiple times to be genetically and epigenetically modified in breast tumours [36-41]; its expression has been reported to be protective against HER2-driven breast tumour development [42]; whereas reduced expression is associated with poor prognosis [43]. A germline intronic deletion in FHIT has also been identified in a pancreatic cancer study [60]. Given that we have found a constitutional $\mathrm{CNV}$ in FHIT we suggest that variants in this gene could also account for a fraction of $\mathrm{fBC}$ patients. As we were unable to obtain other family members it remains to be seen if these genomic re-arrangements confer significant disease risk in a family setting rather than being associated with disease progression.

A recent report using 68 patient and 100 controls suggested that rare CNVs may contribute to disease in a small proportion of $\mathrm{fBC}$ patients [24]. In contrast to our findings this study reported significantly lower percentages of rare CNVs in $\mathrm{fBC}$ patients (4\%) compared to the level observed in the current study (30.65\%) [24]. The discrepancies in these findings are most likely to be related to differences in sample populations, the type of array used (variation in array coverage and density), as well as the algorithm used by the analysis software [44-46]. These findings reinforce the need to obtain larger cohorts of patients and controls to better understand the contribution of CNVs to breast cancer development.

\section{Conclusions}

This study has revealed that there are a number of CNVs which may contribute to the development of fBC. Several previously reported $B C$ susceptibility genes that include RPA3, NBN, MRE11A and CYP19A1 were found to be influenced by the presence of a CNV. It was also revealed by this investigation that three unrelated $\mathrm{ABC}$ patients harboured CNVs in WWOX and FHIT. We propose that variants in these genes may account for disease in a significant proportion of $\mathrm{fBC}$ patients. Overall the results of this study provide further grounds for further investigation into the presence of CNVs in larger series of $\mathrm{ABC}$ patients who do not harbour changes in known breast cancer susceptibility genes.

\section{Additional file}

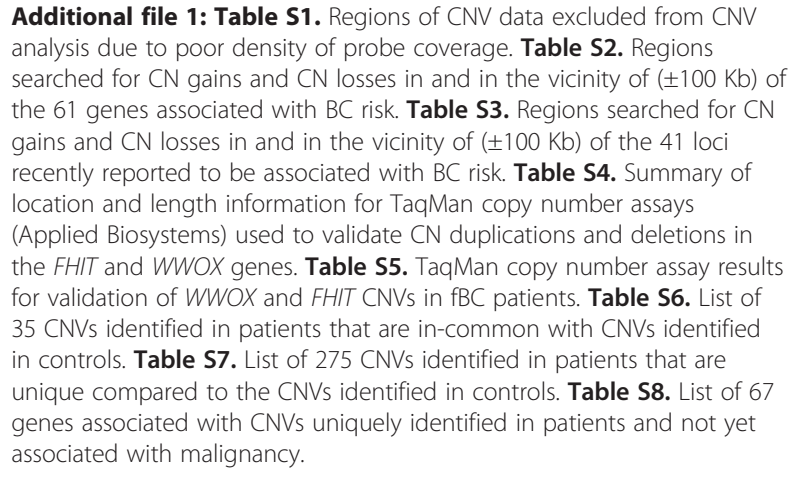

Additional file 1: Table S1. Regions of CNV data excluded from CNV analysis due to poor density of probe coverage. Table S2. Regions searched for $\mathrm{CN}$ gains and $\mathrm{CN}$ losses in and in the vicinity of $( \pm 100 \mathrm{~Kb})$ of the 61 genes associated with BC risk. Table S3. Regions searched for CN gains and $\mathrm{CN}$ losses in and in the vicinity of $( \pm 100 \mathrm{~Kb})$ of the 41 loci recently reported to be associated with BC risk. Table S4. Summary of location and length information for TaqMan copy number assays (Applied Biosystems) used to validate CN duplications and deletions in the FHIT and WWOX genes. Table S5. TaqMan copy number assay results for validation of WWOX and FHIT CNVs in fBC patients. Table S6. List of 35 CNVs identified in patients that are in-common with CNVs identified in controls. Table S7. List of 275 CNVs identified in patients that are unique compared to the CNVs identified in controls. Table S8. List of 67 genes associated with CNVs uniquely identified in patients and not yet associated with malignancy.

\section{Abbreviations}

BC: Breast Cancer; bp: Base pair; CGC: Cancer Gene Census; ChAS: Chromosome Analysis Suite (Affymetrix); CN: Copy Number; CNV: Copy Number Variants; Cyto2.7 M: Cytogenetic Whole Genome 2.7 M array; DGV: Database of Genomic Variants; DSB: Double Strand Breat; DSBR: DSB Repair; fBC: Familial Breast Cancer; HCS: Hunter Community Study; Kb: Kilobase; mapd: Median of absolute pair-wise difference; Mb: Megabase; MLPA: Multiplex Ligation-dependant Probe Amplification; MMR: Mismatch Repair; NCG: Network of Cancer Genes; NTC: No template control; QC: Quality control; SNP: Single nucleotide polymorphism; WavinessSd: Waviness standard deviation.

\section{Competing interests}

The authors declare that they have no competing interest.

\section{Authors' contributions}

ALM conducted the experiments and wrote the first draft of the manuscript. BAT-P, T-JE and DMG provided expertise in data analysis and interpretation as well as revising the manuscript. GNH provided critical review of the manuscript and helped design the experiments. RJS conceived the study, designed the experimental approach and reviewed and approved the final version of the manuscript prior to submission.

\section{Acknowledgements}

This work has been supported by the following funding bodies and institutions: Australian Rotary Health/Rotary District 9650, the Commonwealth Scientific and Industrial Research Organization (CSIRO), the University of Newcastle and the Hunter Medical Research Institute. Samples were provided by the Hunter Area Pathology Service and the Hunter Community Study. 


\section{Author details}

'Information Based Medicine Program, Hunter Medical Research Institute, University of Newcastle, Newcastle, NSW 2305, Australia. ${ }^{2}$ CSIRO Preventative Health Flagship and Animal, CSIRO Food and Health Sciences Division, North Ryde, NSW 2113, Australia. ${ }^{3}$ Division of Molecular Medicine, Hunter Area Pathology Service, John Hunter Hospital, Newcastle, NSW 2305, Australia. ${ }^{4}$ School of Biomedical Sciences and Pharmacy, Faculty of Health, University of Newcastle, Newcastle, NSW 2308, Australia.

\section{Received: 6 March 2014 Accepted: 14 May 2014}

Published: 24 May 2014

\section{References}

1. Jemal A, Bray F, Center MM, Ferlay J, Ward E, Forman D: Global cancer statistics. CA Canc J Clin 2011, 61:69-90

2. Lalloo F, Evans DG: Familial breast cancer. Clin Genet 2012, 82:105-114.

3. Peto J, Mack TM: High constant incidence in twins and other relatives of women with breast cancer. Nat Genet 2000, 26:411-414.

4. Gracia-Aznarez FJ, Fernandez V, Pita G, Peterlongo P, Dominguez O, de la Hoya M, Duran M, Osorio A, Moreno L, Gonzalez-Neira A, Rosa-Rosa JM, Sinilnikova O, Mazoyer S, Hopper J, Lazaro C, Southey M, Odefrey F, Manoukian S, Catucci I, Caldes T, Lynch HT, Hilbers FS, van Asperen CJ, Vasen HF, Goldgar D, Radice $P$, Devilee $P$, Benitez J: Whole exome sequencing suggests much of non-BRCA1/BRCA2 familial breast cancer is due to moderate and low penetrance susceptibility alleles. PLoS One 2013, 8:e55681.

5. Wong MW, Nordfors C, Mossman D, Pecenpetelovska G, Avery-Kiejda KA Talseth-Palmer B, Bowden NA, Scott RJ: BRIP1, PALB2, and RAD51C mutation analysis reveals their relative importance as genetic susceptibility factors for breast cancer. Breast Canc Res Treat 2011, 127:853-859.

6. Zhang B, Beeghly-Fadiel A, Long J, Zheng W: Genetic variants associated with breast-cancer risk: comprehensive research synopsis, meta-analysis, and epidemiological evidence. Lancet Oncol 2011, 12:477-488.

7. Michailidou K, Hall P, Gonzalez-Neira A, Ghoussaini M, Dennis J, Milne RL, Schmidt MK, Chang-Claude J, Bojesen SE, Bolla MK, Wang Q, Dicks E, Lee A, Turnbull C, Rahman N, Breast, Ovarian Cancer Susceptibility, C, Fletcher O, Peto J, Gibson L, Dos Santos Silva I, Nevanlinna H, Muranen TA, Aittomaki K, Blomqvist C, Czene K, Irwanto A, Liu J, Waisfisz Q, Meijers-Heijboer H, Adank M, De La Chapelle A, Peltomaki P: Large-scale genotyping identifies 41 new loci associated with breast cancer risk. Nat Genet 2013, 45:353-361.

8. Palles C, Cazier JB, Howarth KM, Domingo E, Jones AM, Broderick P, Kemp Z, Spain SL, Guarino Almeida E, Salguero I, Sherborne A, Chubb D, Carvajal-Carmona LG, Ma Y, Kaur K, Dobbins S, Barclay E, Gorman M, Martin L, Kovac MB, Humphray S, Consortium C, Consortium WGS, Lucassen A, Holmes CC, Bentley D, Donnelly P, Taylor J, Petridis C, Roylance R, et al: Germline mutations affecting the proofreading domains of POLE and POLD1 predispose to colorectal adenomas and carcinomas. Nat Genet 2013, 45:136-144

9. Lynch HT, de la Chapelle A: Genetic susceptibility to non-polyposis colorectal cancer. J Med Genet 1999, 36:801-818.

10. Kuiper RP, Vissers LE, Venkatachalam R, Bodmer D, Hoenselaar E, Goossens M, Haufe A, Kamping E, Niessen RC, Hogervorst FB, Gille JJ, Redeker B, Tops CM, van Gijn ME, van den Ouweland AM, Rahner N, Steinke V, Kahl P, Holinski-Feder E, Morak M, Kloor M, Stemmler S, Betz B, Hutter P, Bunyan DJ, Syngal S, Culver JO, Graham T, Chan TL, Nagtegaal ID, et al: Recurrence and variability of germline EPCAM deletions in Lynch syndrome. Hum Mutat 2011, 32:407-414.

11. Ligtenberg MJ, Kuiper RP, Chan TL, Goossens M, Hebeda KM, Voorendt M, Lee TY, Bodmer D, Hoenselaar E, Hendriks-Cornelissen SJ, Tsui WY, Kong CK, Brunner HG, van Kessel AG, Yuen ST, van Krieken JH, Leung SY, Hoogerbrugge N: Heritable somatic methylation and inactivation of $\mathrm{MSH} 2$ in families with Lynch syndrome due to deletion of the 3' exons of TACSTD1. Nat Genet 2009, 41:112-117.

12. Chan TL, Yuen ST, Ho JW, Chan AS, Kwan K, Chung LP, Lam PW, Tse CW, Leung SY: A novel germline 1.8-kb deletion of hMLH1 mimicking alternative splicing: a founder mutation in the Chinese population. Oncogene 2001, 20:2976-2981.

13. Nystrom-Lahti M, Kristo P, Nicolaides NC, Chang SY, Aaltonen LA, Moisio AL, Jarvinen HJ, Mecklin JP, Kinzler KW, Vogelstein B, De La Chapelle A, Peltomaki P: Founding mutations and Alu-mediated recombination in hereditary colon cancer. Nat Med 1995, 1:1203-1206.

14. Stella A, Surdo NC, Lastella P, Barana D, Oliani C, Tibiletti MG, Viel A, Natale C, Piepoli A, Marra G, Guanti G: Germline novel MSH2 deletions and a founder
MSH2 deletion associated with anticipation effects in HNPCC. Clin Genet 2007, 71:130-139.

15. Plaschke J, Ruschoff J, Schackert HK: Genomic rearrangements of hMSH6 contribute to the genetic predisposition in suspected hereditary non-polyposis colorectal cancer syndrome. J Med Genet 2003, 40:597-600.

16. Delnatte C, Sanlaville D, Mougenot JF, Vermeesch JR, Houdayer C, Blois MC, Genevieve D, Goulet O, Fryns JP, Jaubert F, Vekemans M, Lyonnet S, Romana S, Eng C, Stoppa-Lyonnet D: Contiguous gene deletion within chromosome arm $10 \mathrm{q}$ is associated with juvenile polyposis of infancy, reflecting cooperation between the BMPR1A and PTEN tumor-suppressor genes. Am J Hum Genet 2006, 78:1066-1074.

17. van Hattem WA, Brosens LA, de Leng WW, Morsink FH, Lens S, Carvalho R, Giardiello FM, Offerhaus GJ: Large genomic deletions of SMAD4, BMPR1A and PTEN in juvenile polyposis. Gut 2008, 57:623-627.

18. Alonso-Espinaco V, Giraldez MD, Trujillo C, van der Klift H, Munoz J, Balaguer F, Ocana T, Madrigal I, Jones AM, Echeverry MM, Velez A, Tomlinson I, Mila M, Wijnen J, Carvajal-Carmona L, Castells A, Castellvi-Bel S: Novel MLH1 duplication identified in Colombian families with Lynch syndrome. Genet Med 2011, 13:155-160.

19. Morak M, Koehler U, Schackert HK, Steinke V, Royer-Pokora B, Schulmann K, Kloor M, Hochter W, Weingart J, Keiling C, Massdorf T, Holinski-Feder E: Biallelic MLH1 SNP CDNA expression or constitutional promoter methylation can hide genomic rearrangements causing Lynch syndrome. J Med Genet 2011, 48:513-519.

20. Clendenning M, Buchanan DD, Walsh MD, Nagler B, Rosty C, Thompson B, Spurdle AB, Hopper JL, Jenkins MA, Young JP: Mutation deep within an intron of MSH2 causes Lynch syndrome. Fam Canc 2011, 10:297-301.

21. Charames GS, Ramyar L, Mitri A, Berk T, Cheng H, Jung J, Bocangel P, Chodirker B, Greenberg C, Spriggs E, Bapat B: A large novel deletion in the APC promoter region causes gene silencing and leads to classical familial adenomatous polyposis in a Manitoba Mennonite kindred. Hum Genet 2008, 124:535-541.

22. Rohlin A, Engwall Y, Fritzell K, Goransson K, Bergsten A, Einbeigi Z, Nilbert M, Karlsson P, Bjork J, Nordling M: Inactivation of promoter 1B of APC causes partial gene silencing: evidence for a significant role of the promoter in regulation and causative of familial adenomatous polyposis. Oncogene 2011, 30:4977-4989.

23. Giarola M, Stagi L, Presciuttini S, Mondini P, Radice MT, Sala P, Pierotti MA, Bertario L, Radice P: Screening for mutations of the APC gene in 66 Italian familial adenomatous polyposis patients: evidence for phenotypic differences in cases with and without identified mutation. Hum Mutat 1999, 13:116-123.

24. Krepischi AC, Achatz Ml, Santos EM, Costa SS, Lisboa BC, Brentani H, Santos TM, Goncalves A, Nobrega AF, Pearson PL, Vianna-Morgante AM, Carraro DM, Brentani RR, Rosenberg C: Germline DNA copy number variation in familial and early-onset breast cancer. Breast Canc Res 2012, 14:R24.

25. Suehiro Y, Okada T, Shikamoto N, Zhan Y, Sakai K, Okayama N, Nishioka M, Furuya T, Oga A, Kawauchi S, Maeda N, Tamesa M, Nagashima Y, Yamamoto S, Oka M, Hinoda Y, Sasaki K: Germline copy number variations associated with breast cancer susceptibility in a Japanese population. Tumour Biol 2013, 34:947-952.

26. McEvoy M, Smith W, D'Este C, Duke J, Peel R, Schofield P, Scott R, Byles J, Henry D, Ewald B, Hancock S, Smith D, Attia J: Cohort profile: The Hunter Community Study. Int J Epidemiol 2010, 39:1452-1463.

27. Miller SA, Dykes DD, Polesky HF: A simple salting out procedure for extracting DNA from human nucleated cells. Nucleic Acids Res 1988, $16: 1215$.

28. Murata H, Khattar NH, Gu L, Li GM: Roles of mismatch repair proteins $\mathrm{hMSH} 2$ and $\mathrm{hMLH} 1$ in the development of sporadic breast cancer. Canc Lett 2005, 223:143-150

29. Vodusek AL, Novakovic S, Stegel V, Jereb B: Genotyping of BRCA1, BRCA2, p53, CDKN2A, MLH1 and MSH2 genes in a male patient with secondary breast cancer. Radiol Oncol 2011, 45:296-299.

30. Cancer Gene Census: Cancer Genome Project Wellcome Trust Sanger Institute; 2012.

31. D'Antonio M, Pendino V, Sinha S, Ciccarelli FD: Network of Cancer Genes (NCG 3.0): integration and analysis of genetic and network properties of cancer genes. Nucleic Acids Res 2012, 40:D978-D983.

32. QuickCalcs - T test: GraphPad Software Inc., GraphPad Software Inc.; 2013.

33. Chang NS, Pratt N, Heath J, Schultz L, Sleve D, Carey GB, Zevotek N: Hyaluronidase induction of a WW domain-containing oxidoreductase 
that enhances tumor necrosis factor cytotoxicity. J Biol Chem 2001, 276:3361-3370

34. Abdeen SK, Salah Z, Maly B, Smith Y, Tufail R, Abu-Odeh M, Zanesi N, Croce CM, Nawaz Z, Aqeilan Rl: Wwox inactivation enhances mammary tumorigenesis. Oncogene 2011, 30:3900-3906.

35. Ekizoglu S, Muslumanoglu M, Dalay N, Buyru N: Genetic alterations of the WWOX gene in breast cancer. Med Oncol 2012, 29:1529-1535.

36. Campiglio M, Pekarsky Y, Menard S, Tagliabue E, Pilotti S, Croce CM: FHIT loss of function in human primary breast cancer correlates with advanced stage of the disease. Canc Res 1999, 59:3866-3869.

37. Cecener G, Egeli U, Tunca B, Tasdelen I, Tolunay S, Bilgel N: Importance of novel sequence alterations in the FHIT gene on formation of breast cancer. Tumori 2007, 93:597-603.

38. Iliopoulos D, Guler G, Han SY, Druck T, Ottey M, McCorkell KA, Huebner K: Roles of FHIT and WWOX fragile genes in cancer. Canc Lett 2006, 232:27-36.

39. Ismail HM, Medhat AM, Karim AM, Zakhary NI: Multiple patterns of FHIT gene homozygous deletion in Egyptian breast cancer patients. Int J Breast Canc 2011, 2011:325947.

40. Ismail HM, Medhat AM, Karim AM, Zakhary NI: FHIT gene and flanking region on chromosome $3 p$ are subjected to extensive allelic loss in Egyptian breast cancer patients. Mol Carcinog 2011, 50:625-634.

41. Negrini M, Monaco C, Vorechovsky I, Ohta M, Druck T, Baffa R, Huebner K, Croce CM: The FHIT gene at 3p14.2 is abnormal in breast carcinomas. Canc Res 1996, 56:3173-3179.

42. Bianchi F, Tagliabue E, Menard S, Campiglio M: Fhit expression protects against HER2-driven breast tumor development: unraveling the molecular interconnections. Cell Cycle 2007, 6:643-646.

43. Arun B, Kilic G, Yen C, Foster B, Yardley DA, Gaynor R, Ashfaq R: Loss of FHIT expression in breast cancer is correlated with poor prognostic markers. Canc Epidemiol Biomarkers Prev 2005, 14:1681-1685.

44. Dellinger AE, Saw SM, Goh LK, Seielstad M, Young TL, Li YJ: Comparative analyses of seven algorithms for copy number variant identification from single nucleotide polymorphism arrays. Nucleic Acids Res 2010, 38:e105.

45. Tsuang DW, Millard SP, Ely B, Chi P, Wang K, Raskind WH, Kim S, Brkanac Z, YU CE: The effect of algorithms on copy number variant detection. PLOS One 2010, 5:e14456.

46. Zhang D, Qian Y, Akula N, Alliey-Rodriguez N, Tang J, Bipolar Genome S, Gershon ES, Liu C: Accuracy of CNV Detection from GWAS Data. PLoS One 2011, 6:e14511.

47. Yoshihara K, Tajima A, Adachi S, Quan J, Sekine M, Kase H, Yahata T, Inoue I, Tanaka K: Germline copy number variations in BRCA1-associated ovarian cancer patients. Genes Chromosomes Canc 2011, 50:167-177.

48. Zhang B, Kirov S, Snoddy J: WebGestalt: an integrated system for exploring gene sets in various biological contexts. Nucleic Acids Res 2005, 33:W741-W748.

49. Ong DC, Ho YM, Rudduck C, Chin K, Kuo WL, Lie DK, Chua CL, Tan PH, Eu KW, Seow-Choen F, Wong CY, Hong GS, Gray JW, Lee AS: LARG at chromosome $11 \mathrm{q} 23$ has functional characteristics of a tumor suppressor in human breast and colorectal cancer. Oncogene 2009, 28:4189-4200.

50. Sathyanarayana UG, Padar A, Huang CX, Suzuki M, Shigematsu H, Bekele BN, Gazdar AF: Aberrant promoter methylation and silencing of laminin-5-encoding genes in breast carcinoma. Clin Canc Res 2003, 9:6389-6394.

51. Bajrami I, Kigozi A, Van Weverwijk A, Brough R, Frankum J, Lord CJ, Ashworth A: Synthetic lethality of PARP and NAMPT inhibition in triple-negative breast cancer cells. EMBO Mol Med 2012, 4:1087-1096.

52. Gothlin Eremo A, Wegman P, Stal O, Nordenskjold B, Fornander T, Wingren S: Wwox expression may predict benefit from adjuvant tamoxifen in randomized breast cancer patients. Oncol Rep 2013, 29:1467-1474.

53. Bartkova J, Tommiska J, Oplustilova L, Aaltonen K, Tamminen A, Heikkinen T, Mistrik M, Aittomaki K, Blomqvist C, Heikkila P, Lukas J, Nevanlinna H, Bartek J: Aberrations of the MRE11-RAD50-NBS1 DNA damage sensor complex in human breast cancer: MRE11 as a candidate familial cancer-predisposing gene. Mol Oncol 2008, 2:296-316.

54. Heikkinen K, Karppinen SM, Soini Y, Makinen M, Winqvist R: Mutation screening of Mre11 complex genes: indication of RAD50 involvement in breast and ovarian cancer susceptibility. J Med Genet 2003, 40:e131.

55. Hsu HM, Wang HC, Chen ST, Hsu GC, Shen CY, Yu JC: Breast cancer risk is associated with the genes encoding the DNA double-strand break repair Mre11/Rad50/Nbs1 complex. Canc Epidemiol Biomarkers Prev 2007, 16:2024-2032
56. Yuan SS, Hou MF, Hsieh YC, Huang CY, Lee YC, Chen YJ, Lo S: Role of MRE11 in cell proliferation, tumor invasion, and DNA repair in breast cancer. J Natl Canc Inst 2012, 104:1485-1502.

57. Chang XZ, Li DQ, Hou YF, Wu J, Lu JS, Di GH, Jin W, Ou ZL, Shen ZZ, Shao $\mathrm{ZM}$ : Identification of the functional role of AF1Q in the progression of breast cancer. Breast Canc Res Treat 2008, 111:65-78.

58. Li DQ, Hou YF, Wu J, Chen Y, Lu JS, Di GH, Ou ZL, Shen ZZ, Ding J, Shao ZM: Gene expression profile analysis of an isogenic tumour metastasis model reveals a functional role for oncogene AF1Q in breast cancer metastasis. Eur J Canc 2006, 42:3274-3286.

59. Naylor TL, Greshock J, Wang Y, Colligon T, Yu QC, Clemmer V, Zaks TZ, Weber BL: High resolution genomic analysis of sporadic breast cancer using array-based comparative genomic hybridization. Breast Canc Res 2005, 7:R1186-R1198.

60. Lucito R, Suresh S, Walter K, Pandey A, Lakshmi B, Krasnitz A, Sebat J, Wigler M, Klein AP, Brune K, Palmisano E, Maitra A, Goggins M, Hruban RH: Copy-number variants in patients with a strong family history of pancreatic cancer. Canc Biol Ther 2007, 6:1592-1599.

doi:10.1186/1897-4287-12-15

Cite this article as: Masson et al.: Expanding the genetic basis of copy number variation in familial breast cancer. Hereditary Cancer in Clinical Practice 2014 12:15.

\section{Submit your next manuscript to BioMed Central and take full advantage of:}

- Convenient online submission

- Thorough peer review

- No space constraints or color figure charges

- Immediate publication on acceptance

- Inclusion in PubMed, CAS, Scopus and Google Scholar

- Research which is freely available for redistribution 